\title{
A Label-free Aptasensor for Rapid Detection of H1N1 Virus based on Graphene Oxide and Polymerase-aided Signal Amplification
}

\author{
Xinru Feng', Keyi Liu', Yi Ning ${ }^{1,2}$, Lijuan Chen ${ }^{1,2}$ and Le Deng ${ }^{1 *}$ \\ ${ }^{1}$ Department of Microbiology, College of Life Science, Hunan Normal University, Changsha, Hunan, People's Republic of China
}

${ }^{2}$ College of Medicine, Hunan University of Traditional Chinese Medicine, Changsha, Hunan, People's Republic of China

\begin{abstract}
Single-stranded DNA aptamers specific to the hemagglutinin (HA) protein of avian influenza virus (A/Puerto Rico/8/1934) were obtained by SELEX process in 13 cycles. The aptamer with the highest affinity and specificity was applied to an affinity bioassay. An aptamer hairpin (aHP) was prepared that consists of two DNA regions, viz. (a) the aptamer for the HA protein and (b) an oligonucleotide designed to form a stem-loop structure. In the absence of target, the aHP maintains its hairpin structure and was adsorbed to the Graphene Oxide (GO). The fluorescence of SYBR Green I (SGI) is almost quenched. On addition of the target, aHP unfolds and the GO is no longer attached but released to the solution. By applying a polymerase elongation reaction, a long dsDNA product is generated when SGI is added. The proposed method could detect $\mathrm{HA}$ and $\mathrm{H} 1 \mathrm{~N} 1$ virus with a limit of $2.5 \mu \mathrm{g} / \mathrm{mL}$ and $1 \times 10^{2} \mathrm{TCID} 50$, respectively. Consequently, this paves the way for influenza virus detection and is employed in basic research and medical diagnosis.
\end{abstract}

Keywords: Aptamer; Influenza virus; Graphene oxide; Detection

\section{Introduction}

Influenza virus belongs to the Orthomyxoviridae family and includes three types: A, B and C. Among these types, the influenza A virus leads to seasonal epidemics, sporadic pandemics, which are the major causes of morbidity and mortality. Influenza, an acute infectious disease, is a major source of fever, cough, runny nose and other symptoms of humans and has a great impact on public health. It is estimated that seasonal influenza virus strains infections caused 50,000 deaths each year. These symptoms are actually closely related to the HA. The HA, a glycoprotein, is a spike located on the surface of influenza virus' envelope which is responsible for hemagglutination. It is reported that the HA could bind to sialic acid receptors located on the surface of host cells and mediated the subsequent entry via membrane fusion which is significant for initial viral infection [13]. It is proteolytically hydrolyzed to HA1 and HA2 subunits. HA1 is receptor-binding domain while HA2 fusion peptide inserts itself into the endosomal membrane, allowing contact of both the viral and endosomal membranes [4]. Accordingly, HA could be employed as a biomarker for detection and as an important target for depressing its function.

Aptamers, as promising alternatives to antibodies, are ssDNA and RNA molecules obtained from the Systematic Evolution of Ligands by Exponential enrichment (SELEX) process that can bind to a wide range of target molecules with high specificity and affinity, including protein, organic molecules, drugs, various cell surface receptors, and whole cells, to name a few [5-7]. They have been applied to detect pathogenic bacteria, separate the targets, and identify biomarkers $[8,9]$. Meanwhile, they have also been employed as an efficient therapeutic tool against viruses due to their remarkable properties [10-12]. So far, several high-affinity DNA and RNA aptamers have been successfully applied in suppressing the function of viral proteins, such as human immunodeficiency virus HIV glycoprotein 120 (gp120) [13], human hepatitis B virus polymerase (P protein) [14] and influenza virus NS1 protein [15]. In the past five years, there are already quite some reported works for the selection of HA aptamer by SELEX process. The aptamers selected by Gopinath had a higher affinity and specificity for the HA of H1N1 [16]. However, they were RNA and not stable. The function of DNA aptamer selected by Jeon was to target HA protein of influenza virus and inhibit it, which may be promising candidate for treatment of influenza virus infection [17].

Park paid attention to hemagglutination inhibition test in vitro with selected aptamer [18]. However, few works have been reported on aptamers for H1N1 (A/Puerto Rico/8/1934) influenza virus' detection. Hence, it is necessary to screen a DNA aptamer with highly specificity to the HA protein of the virus $\mathrm{H} 1 \mathrm{~N} 1$, and use it to establish a sensitive detection system.

Graphene oxide (GO), a two-dimensional nanomaterial, is an efficient bioanalytical platform for the detection of nucleic acids, proteins, metal ions, and small molecules [19-21], drawing wide attention due to its unique and excellent electronic, thermal, and mechanical properties [22-24]. GO makes fluorescence detection promising application in sensing technology $[25,26]$. Herein, a novel label-free fluorescent approach was constructed for H1N1 detection in conformity with GO and strand displacement reaction by employing SYBR Green I (SGI) for signal amplification. Once target was bound with the aptamer sequence of the hairpin probe (HP), another sequence could form a self-assembled short hairpin structure. Meanwhile, strand displacement reaction would be triggered by generating a large amount of dsDNA in the presence of KF polymerase and dNTPs. Upon addition of GO, the SGI-stained dsDNA would be inefficiently quenched by it, resulting in a significant fluorescence enhancement. In the absence of target, the stained HP would be absorbed onto GO and quenched by it.

*Corresponding author: Le Deng, Department of Microbiology, College of Life Science, Hunan Normal University, Changsha, Hunan, 410081, P.R China, Tel: 86-0731-88872927; Fax: 86-0731 88883310; E-mail: dengle@hunnu.edu.cn

Received March 09, 2015; Accepted April 13, 2015; Published May 05, 2015

Citation: Feng X, Liu K, Ning Y, Chen L, Deng L (2015) A Label-free Aptasensor for Rapid Detection of H1N1 Virus based on Graphene Oxide and Polymeraseaided Signal Amplification. J Nanomed Nanotechnol 6: 288. doi:10.4172/21577439.1000288

Copyright: ( 2015 Feng X, et al. This is an open-access article distributed under the terms of the Creative Commons Attribution License, which permits unrestricted use, distribution, and reproduction in any medium, provided the original author and source are credited. 
Citation: Feng X, Liu K, Ning Y, Chen L, Deng L (2015) A Label-free Aptasensor for Rapid Detection of H1N1 Virus based on Graphene Oxide and Polymerase-aided Signal Amplification. J Nanomed Nanotechnol 6: 288. doi:10.4172/2157-7439.1000288

\section{Materials and Methods}

\section{Materials}

A synthetic ssDNA library containing a 35-base central random sequence (5'-GGGAGCTCAGAATAAACGCTCAA-N35-TTCGAC ATGAGGCCCGGATC-3') were synthesized by Shanghai Sangon Biological Engineering Technology \& Services Co., Ltd (Shanghai, China, http://www.sangon.com). Polymerase Klenow Fragment (2 $\mathrm{U} / \mu \mathrm{L})$ and $10 \times$ Klenow Fragment buffer $(500 \mathrm{mM}$ Tris-HCl, $50 \mathrm{mM}$ $\mathrm{MgCl}_{2}, 10 \mathrm{mM}$ DTT, $\mathrm{pH} 8.0$ ) were also obtained from Sangon Biotech Co., Ltd. (Shanghai, China). All materials used in the experiment were dissolved in distilled water purified by a Milli-Q water purification system (electric resistivity $18 \mathrm{M} \Omega \mathrm{cm}^{-}$). All the other chemicals were analytical reagent grades, and were used without further purification. SYBR Green I $\left(10^{4} \times\right.$ concentrate $)$ was purchased from FANBO BIOCHEMICALS Co., Ltd (Beijing, China). Graphite powder was purchased from Nanjing XFNANO Materials Tech Co., Ltd (Nanjing, China, http://www.xfnano.com). The fluorescent emission spectra were recorded in a quartz cuvette by an LS55 luminescence spectrometer (PerkinElmer, UK) at room temperature. The concentration of oligonucleotides were determined by using the absorbance at 260 $\mathrm{nm}$. The recombinant HA protein of AIV subtype H1N1 (A/Puerto Rico/8/1934) with a concentration of $0.25 \mathrm{mg} / \mathrm{mL}$ was offered from Sino Biological Inc. The virus was cultivated in the allantoic cavities of 10 -day-old embryonated chicken eggs and maintained at $35^{\circ} \mathrm{C}$. After $72 \mathrm{~h}$ culturing, the allantoic fluid was centrifuged and the supernatant was harvested, and stored at $-70^{\circ} \mathrm{C}$ prior to use. The titer of virus used for infection was evaluated by the infection of Madin-Darby canine kidney (MDCK) cells [27], and hence, virus titer was expressed as the tissue culture infective doses leading to $50 \%$ infected cells (TCID50). The three strains of virus were A/Chicken/Henan/12/2004 (H5N1), A/ Chicken/Jiangsu/7/2002 (H9N2) and A/Puerto Rico/8/1934 (H1N1) which were maintained in Molecular Virology Lab of Hunan Normal University.

\section{Methods}

SELEX procedure: The oligonucleotide library consisted of a 35-base random region flanked by two primer regions: 5'-GGGAGCTCAGAATAAACGCT CAA-N35TTCGACATGAGGCCCGGATC-3'. The detailed procedure for selecting HA protein aptamers was implemented as follows. The HA protein with $0.05 \mathrm{~mol} / \mathrm{LNaHCO}_{3}$ ( $\mathrm{pH} 9.6$ ) was coated on a 96 -well ELISA Plate at $4^{\circ} \mathrm{C}$ overnight. $3 \%$ bovine serum albumin (BSA) was added at $37^{\circ} \mathrm{C}$ for $2 \mathrm{~h}$ to block the wells coated with HA protein and blank wells. The ssDNA library was denatured at $95^{\circ} \mathrm{C}$ for $5 \mathrm{~min}$ in binding buffer $(20$ $\mathrm{mmol} / \mathrm{L}$ HEPES buffer $\mathrm{pH} 7.35,120 \mathrm{mmol} / \mathrm{L} \mathrm{NaCl}, 1 \mathrm{mmol} / \mathrm{L} \mathrm{MgCl}_{2}, 1$ $\mathrm{mmol} / \mathrm{L} \mathrm{CaCl}_{2}$, and $5 \mathrm{mmol} / \mathrm{L} \mathrm{KCl}$ ) and then immediately placed into iced water for $10 \mathrm{~min}$. To decrease background binding, yeast tRNA was added to the binding buffer from the second round to the end round. For negative selection, ssDNA libraries added to BSA-blocked blank wells were maintained at $37^{\circ} \mathrm{C}$ for $40 \mathrm{~min}$. Uncombined ssDNAs were then transferred to the wells coated with HA protein at $37^{\circ} \mathrm{C}$ for $40 \mathrm{~min}$. The wells were washed five times with washing buffer (binding buffer $+0.05 \%$ Tween 20$)$ and filled with eluting buffer $(20 \mathrm{mmol} / \mathrm{L}$ Tris- $\mathrm{HCl}, 4 \mathrm{~mol} / \mathrm{L}$ guanidiniumisothiocyanate, $1 \mathrm{mmol} / \mathrm{L}$ DTT, $\mathrm{pH}$ 8.3 ) at $80^{\circ} \mathrm{C}$ for $10 \mathrm{~min}$. Subsequently, $3 \mathrm{~mol} / \mathrm{L}$ sodium acetate (pH5.2) and dehydrated ethanol were added and kept at $-80^{\circ} \mathrm{C}$ for $40 \mathrm{~min}$, and centrifuged at $30,857 \times \mathrm{g}$ for $10 \mathrm{~min}$ at $4^{\circ} \mathrm{C}$. The sediment was washed twice by absolute ethyl alcohol and dissolved in $20 \mu \mathrm{L}$ double-distilled water after drying. The ssDNA was amplified by PCR $\left(5 \mathrm{~min}\right.$ at $95^{\circ} \mathrm{C}$, then $30 \mathrm{~s}$ at $95^{\circ} \mathrm{C}, 30 \mathrm{~s}$ at $65^{\circ} \mathrm{C}$, and $30 \mathrm{~s}$ at $72^{\circ} \mathrm{C}, 20$ cycles, followed by $5 \mathrm{~min}$ at $\left.72^{\circ} \mathrm{C}\right)$. The asymmertric PCR $\left(5 \mathrm{~min}\right.$ at $95^{\circ} \mathrm{C}$, then $30 \mathrm{~s}$ at $95^{\circ} \mathrm{C}$, $30 \mathrm{~s}$ at $65^{\circ} \mathrm{C}$, and $30 \mathrm{~s}$ at $72^{\circ} \mathrm{C}, 40$ cycles, followed by $5 \mathrm{~min}$ at $72^{\circ} \mathrm{C}$ ) was used to acquire the ssDNA as the enriched library for the next selection round. The amount of ssDNAs at each step was measured by UV-Vis spectroscopy. The aptamer binding ratio was obtained by analyzing the fluorescence of eluted ssDNA every two rounds. After 13 rounds' enrichment, the PCR products selected from the $13^{\text {th }}$ round were subcloned and sequenced by Shanghai Sangon Biological Engineering Technology and Services Co., Ltd (Shanghai, China). Their secondary structures were performed using the DNAMAN software.

Performance of target protein sensing and selective assay: The sample was mixed with hairpin probe $(5 \mu \mathrm{L}, 50 \mathrm{nM}$ 5'-GGGAGCTCAGAATAAACGCTCAAGGCACGGCATGTGTG GTATGTGGTGCCTGTACTCGTTCGACATGAGGCCCGGATC CATGCTAACAAGCATG-3') in PBS (phosphate buffered saline) buffer at $95^{\circ} \mathrm{C}$ for $5 \mathrm{~min}$ and kept at room temperature for $20 \mathrm{~min}$. After that, the HA proteins ranging from $0 \mu \mathrm{g} / \mathrm{mL}$ to $10 \mu \mathrm{g} / \mathrm{mL}$ were added to the solution. After incubation for $40 \mathrm{~min}, 4 \mu \mathrm{L}$ SGI (50×concentrate) and $1.5 \mu \mathrm{L} \mathrm{GO}(1 \mathrm{mg} / \mathrm{mL})$ were successively injected into the reactions and incubated at $37^{\circ} \mathrm{C}$ for $10 \mathrm{~min}$. The polymerization reaction was then performed by mixing with $10 \mathrm{mM}$ dNTPs and $2 \mathrm{U} / \mathrm{mL} \mathrm{KF}$ polymerase for $10 \mathrm{~min}$, and then terminated by heating at $80^{\circ} \mathrm{C}$ for $5 \mathrm{~min}$. Subsequently, the fluorescence intensity was measured in the quartz cuvette. Fluorescence intensity was recorded at $520 \mathrm{~nm}$ with an excitation wavelength of $496 \mathrm{~nm}$. Bovine serum albumin (BSA), lysozyme and the control were chosen to verify the selectivity of this approach. Their concentrations were $5 \mu \mathrm{g} / \mathrm{mL}$. All experiments were repeated three times.

Analysis of virus sample: After various titers of virus were mixed with hairpin in working solution (PBS) at $37^{\circ} \mathrm{C}$ for $40 \mathrm{~min}$, SGI and GO were added into the systems for $10 \mathrm{~min}$. dNTP and KF polymerase were mixed into the reaction buffer. Continually, the reaction was performed at $37^{\circ} \mathrm{C}$ for $10 \mathrm{~min}$, and the fluorescence signals were measured in a quartz cuvette at an excitation wavelength of $496 \mathrm{~nm}$ and an emission wavelength of $520 \mathrm{~nm}$, respectively. Its specificity was also detected using two different strains:H9N2, H5N1 under the same conditions. All experiments were repeated in triplicates.

\section{Results and Discussion}

\section{In vitro selection of ssDNA aptamers for recognition of the HA protein}

In order to obtain DNA aptamers with high affinity and specificity, thirteen repeated separation-amplification cycles were completed, and the ssDNA and HA protein concentrations decreased with each subsequent selection round. After 13 selection rounds, the aptamers showed higher affinities for HA protein. The amounts of HA protein and ssDNA pools added in each round are shown in Table 1. In addition, the quantity of BSA and yeast tRNA increased with the selection round to ensure the competitive binding. The binding ratios of aptamers against HA increased with the selection process and the percentage of bound ssDNA did not increase considerably after round 11 as shown in Figure S1. These results displayed that the affinity of the ssDNA pool to HA protein appeared to be nearly constant after round 11. After being cloned and sequenced, two independent candidates were acquired and named aptamers 1,2 . The predicted secondary structures of the two aptamers were also determined by DNAMAN software, and their typical stem-loop motifs are shown in Figure 1. As aptamer 1 showed 
Citation: Feng X, Liu K, Ning Y, Chen L, Deng L (2015) A Label-free Aptasensor for Rapid Detection of H1N1 Virus based on Graphene Oxide and Polymerase-aided Signal Amplification. J Nanomed Nanotechnol 6: 288. doi:10.4172/2157-7439.1000288

\begin{tabular}{|c|c|c|c|}
\hline $\begin{array}{c}\text { SELEX } \\
\text { Rounds }\end{array}$ & $\begin{array}{c}\text { HA protein } \\
\text { (ugwell) }\end{array}$ & $\begin{array}{c}\text { ssDNA poll } \\
\text { (pmol/well) }\end{array}$ & $\begin{array}{c}\text { tRNA } \\
\text { (ug/mI) }\end{array}$ \\
\hline 1 & 4 & 400 & 0 \\
\hline 2 & 2 & 200 & 0.125 \\
\hline 3 & 1 & 100 & 0.125 \\
\hline 4 & 0.5 & 100 & 0.25 \\
\hline 5 & 0.5 & 80 & 0.25 \\
\hline 6 & 0.25 & 60 & 0.5 \\
\hline 7 & 0.25 & 50 & 0.5 \\
\hline 8 & 0.1 & 40 & 1 \\
\hline 9 & 0.1 & 30 & 1 \\
\hline 10 & 0.05 & 20 & 1.5 \\
\hline 11 & 0.05 & 10 & 1.5 \\
\hline 12 & 0.05 & 10 & 2 \\
\hline 13 & 0.025 & 5 & 2 \\
\hline
\end{tabular}

Table 1: Hemagglutinin (HA) protein, ssDNA pool and tRNA input in 13 rounds selection.

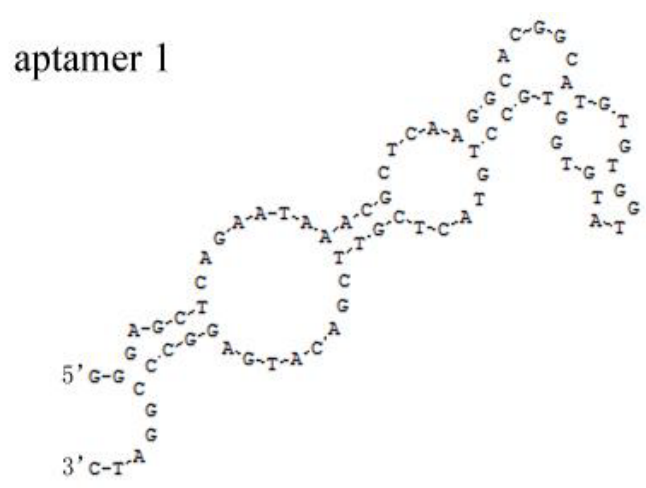

aptamer 2

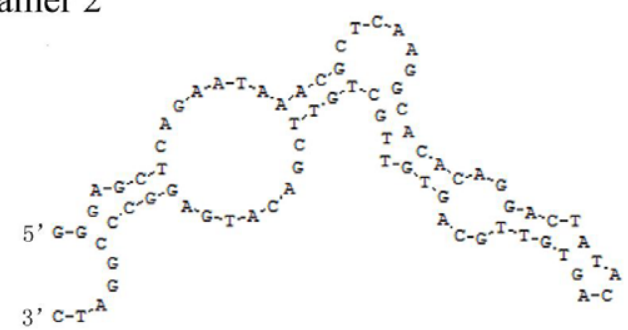

Figure 1: Predicted secondary structures of the selected ssDNA aptamer candidates using DNAMAN software. (a) aptamer sequence 1; (b) aptamer sequence 2 .

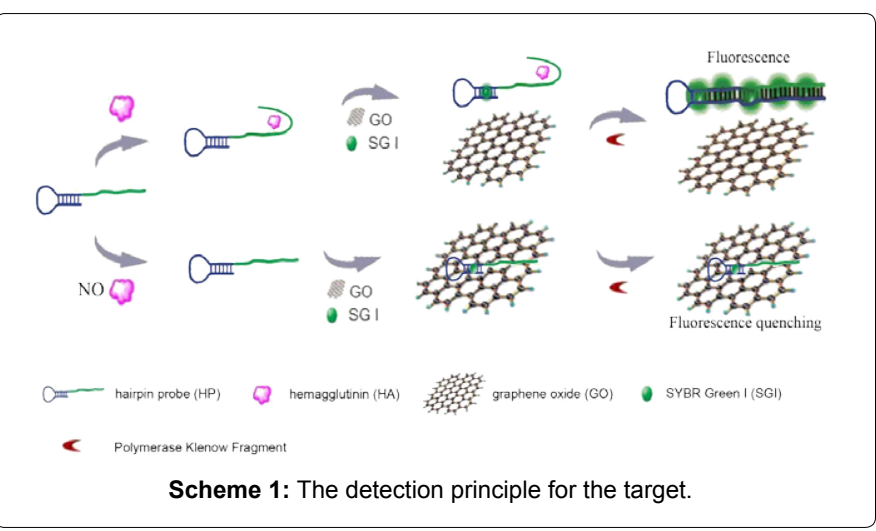

higher binding affinity for HA protein $(\mathrm{Kd}=78 \pm 1 \mathrm{nmol} / \mathrm{L})$ compared with aptamer 2, aptamer1 was selected for further experiments.

\section{Design of rapid detection for target}

Although several similar methods have been reported, however, they have their some shortcomings. Therefore, it is necessary to develop a highly sensitive and selective fluorescent means for HA and H1N1 detection. As shown in Scheme 1, the aptamer hairpin (HP) was composed of two DNA regions including the HA protein aptamer sequence and the oligonucleotide sequence specially designed which could form stem-loop structure. In the absence of HA protein, HP maintained its hairpin structure and its fluorescence signals could not be detected after adding SGI and GO. Because the aptamer was strongly absorbed onto the GO due to $\pi-\pi$ stacking interactions between the nucleotide bases and GO [28], it was resulted in that KF polymerase and dNTPs could not work and the fluorescence was quenched. When the target was added, HP would not be absorbed onto the $\mathrm{GO}$, and polymerase elongation reaction generated a long dsDNA product, triggering a strong increase in the fluorescence intensity upon introducing the SGI. In addition, it was first necessary to examine the ratio of GO and HP to improve the detection efficiency. As shown in Figure 2, the fluorescence decreased obviously with GO increase, and remained stable until its concentration reached $15 \mu \mathrm{g} / \mathrm{mL}$, which suggested the fluorescence of $50 \mathrm{nM}$ HP could be effectively quenched by $15 \mu \mathrm{g} / \mathrm{mL}$ GO via fluorescence resonance energy transfer (FRET) [29]. Thus, $15 \mu \mathrm{g} / \mathrm{mL}$ was chosen as the optimal concentration for next experiments. As for the feasibility assay, Figure 3 showed that the fluorescence of aptamer spiked with GO and SGI was weak (curve b)

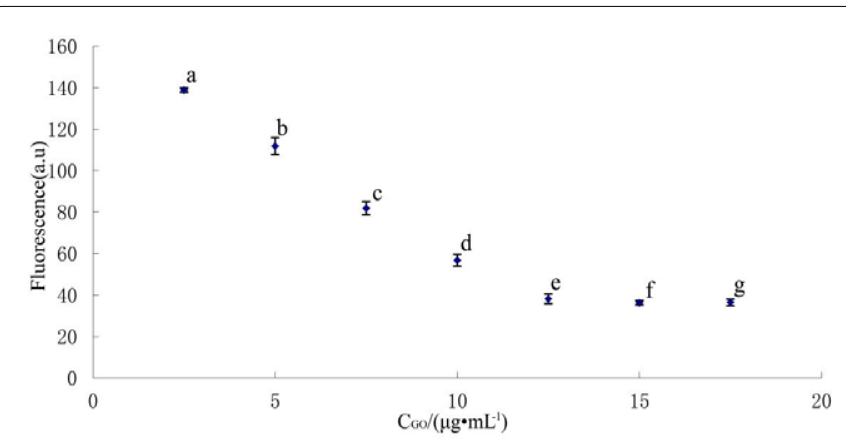

Figure 2: Optimization of concentration ratio of graphene oxide toaptamer (50 nM) with SGI. (a to g: 2.5,5,7.5,10,12.5,15,17.5 $\mu \mathrm{g} / \mathrm{mL}$ ) Excitation: 496 $\mathrm{nm}$. Error bars indicate standard deviation $(n=3)$.

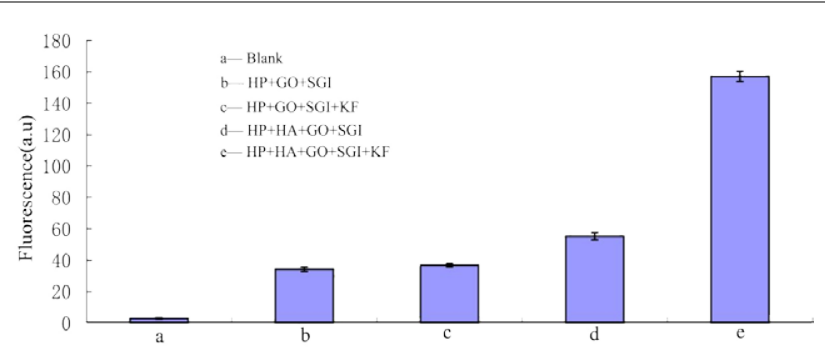

Figure 3: The feasibility of KF polymerase-aided amplification assay. The fluorescence spectras of the proposed method were under different conditions. (a) Blank: buffer; (b) $50 \mathrm{nM} \mathrm{HP}+\mathrm{GO}+\mathrm{SGl}$; (c) $50 \mathrm{nM} \mathrm{HP}+\mathrm{GO}$ + SGI + KF; (d) $50 \mathrm{nM} \mathrm{HP}+\mathrm{HA}+\mathrm{GO}+\mathrm{SGI}$; (e) $50 \mathrm{nM} \mathrm{HP}+\mathrm{HA}+\mathrm{GO}+\mathrm{SGI}$ $+\mathrm{KF}$. The concentrations of $\mathrm{HA}$ protein and $\mathrm{GO}$ were respectively $5 \mu \mathrm{g} / \mathrm{mL}$ and $15 \mu \mathrm{g} / \mathrm{mL}$. Excition: $496 \mathrm{~nm}$, and emission: $520 \mathrm{~nm}$. Error bars indicate standard deviation $(n=3)$. 
Citation: Feng X, Liu K, Ning Y, Chen L, Deng L (2015) A Label-free Aptasensor for Rapid Detection of H1N1 Virus based on Graphene Oxide and Polymerase-aided Signal Amplification. J Nanomed Nanotechnol 6: 288. doi:10.4172/2157-7439.1000288

and nearly the same as the background signals. In the absence of HA, the polymerase elongation reaction would not be triggered, resulting in weak fluorescence signals even after KF polymerase and dNTPs were added (curve c). In the presence of target, fluorescence enhanced slightly (curve d) as the reaction was initiated, and an obvious fluorescence peak appeared upon mixing KF polymerase and dNTPs subsequently (curve e). Therefore, the result revealed clearly that the KF polymerase-aided reaction would increase greatly the fluorescence intensity, which displayed that the assay is feasible for detection HA.

\section{Analysis of sensitivity and selectivity of the assay}

As for the sensitivity assay, Figure 4A displayed that the fluorescence intensity considerably increased with $\mathrm{HA}$ increase ranging from $0 \mu \mathrm{g} /$ $\mathrm{mL}$ to $10 \mu \mathrm{g} / \mathrm{mL}$. The fluorescence intensity showed a linear correlation in $2.5 \mu \mathrm{g} / \mathrm{mL}$ to $7.5 \mu \mathrm{g} / \mathrm{mL}$ (inset of Figure $4 \mathrm{~A}$ ), with a correlation coefficient $\left(\mathrm{R}^{2}=0.9978\right)$, where $\mathrm{Y}$ and $\mathrm{X}$ are the changes of fluorescence intensity and target concentration, respectively. More importantly, the detection limit was $2.5 \mu \mathrm{g} / \mathrm{mL}$ based on theoretical calculation $(3 \sigma$ rule). Additionally, BSA and lysozyme were employed to evaluate the selectivity of this approach. As shown in Figure 4B, the fluorescence signals did not obviously increase after the addition of them, and had substantial enhancement when HA was added. Due to the inherent specificity of the aptamer toward its target, the fluorescence increased remarkably after adding only $\mathrm{HA}$. The result indicated that this method could be applied to detect HA with high specificity. Meanwhile, influenza viruses were also assessed to test the applicability of this method for real sample detection. It was detected sample of the influenza virus with lower detection limit of $1 \times 10^{2}$ TCID50 (Figure $5 \mathrm{~A}$ ). Thus, the method was a highly sensitive way for detecting H1N1.

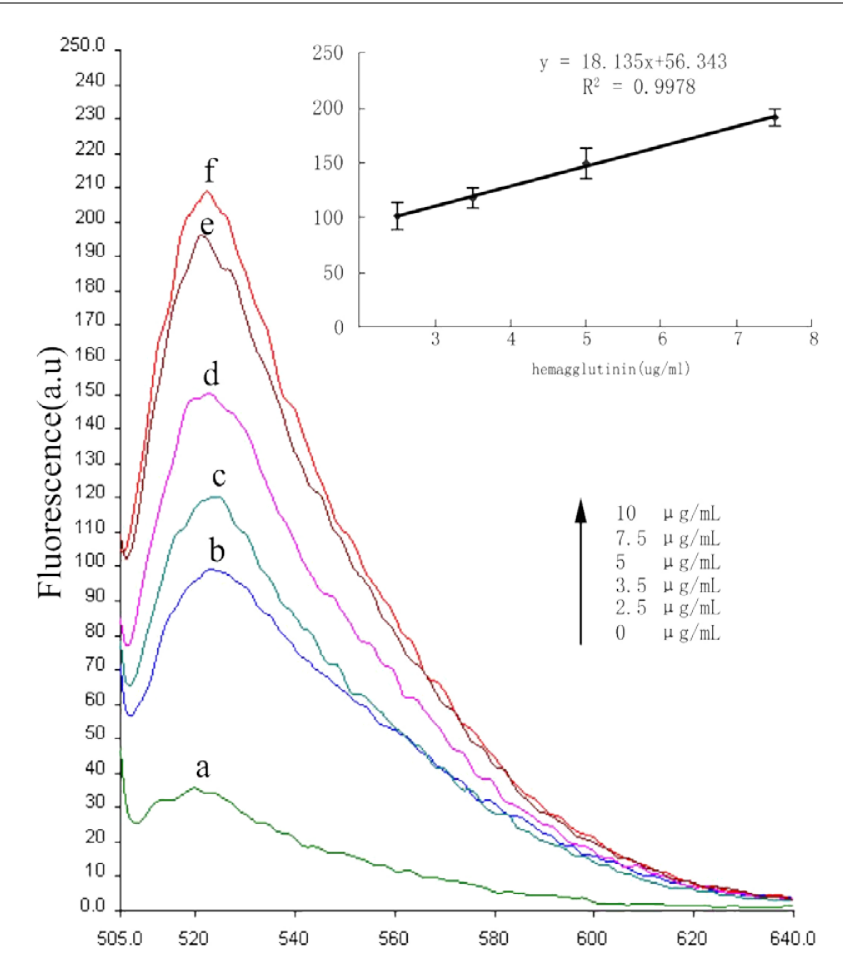

Figure 4a: Fluorescence spectral responses of KF polymeraseaidedamplification assay for $\mathrm{HA}$ protein of varying concentrations (a to f: 0 , $2.5,3.5,5,7.5,10 \mu \mathrm{g} / \mathrm{mL}$ ). Insert: The linear relationship of the fluorescence intensity on $\mathrm{HA}$ protein concentrations from $2.5 \mu \mathrm{g} / \mathrm{mL}$ to $7.5 \mu \mathrm{g} / \mathrm{mL}$. The error bars embody the standard deviations of repeated results.

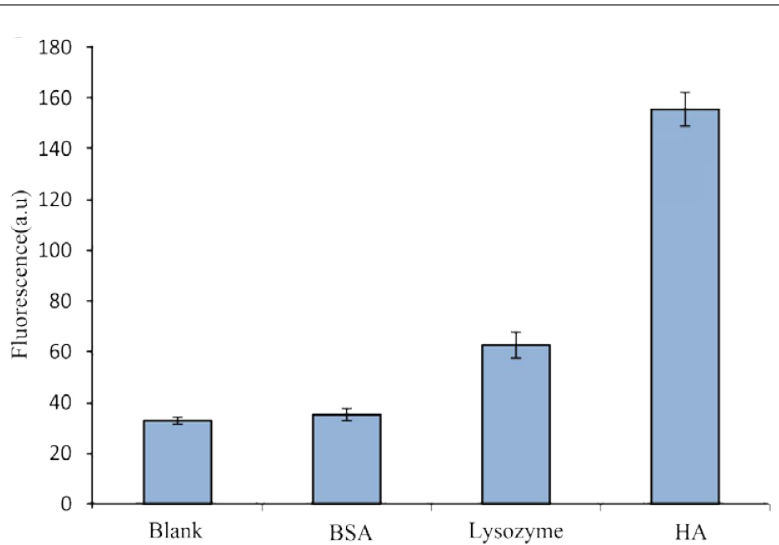

Figure 4b: The specificity of this assay with different targets. (a) Blank,(b) BSA, (c) Lysozyme, (d) A. (all at a concentration of $5 \mu \mathrm{g} / \mathrm{mL}$ ) Each data indicates the average of at least three experiments.

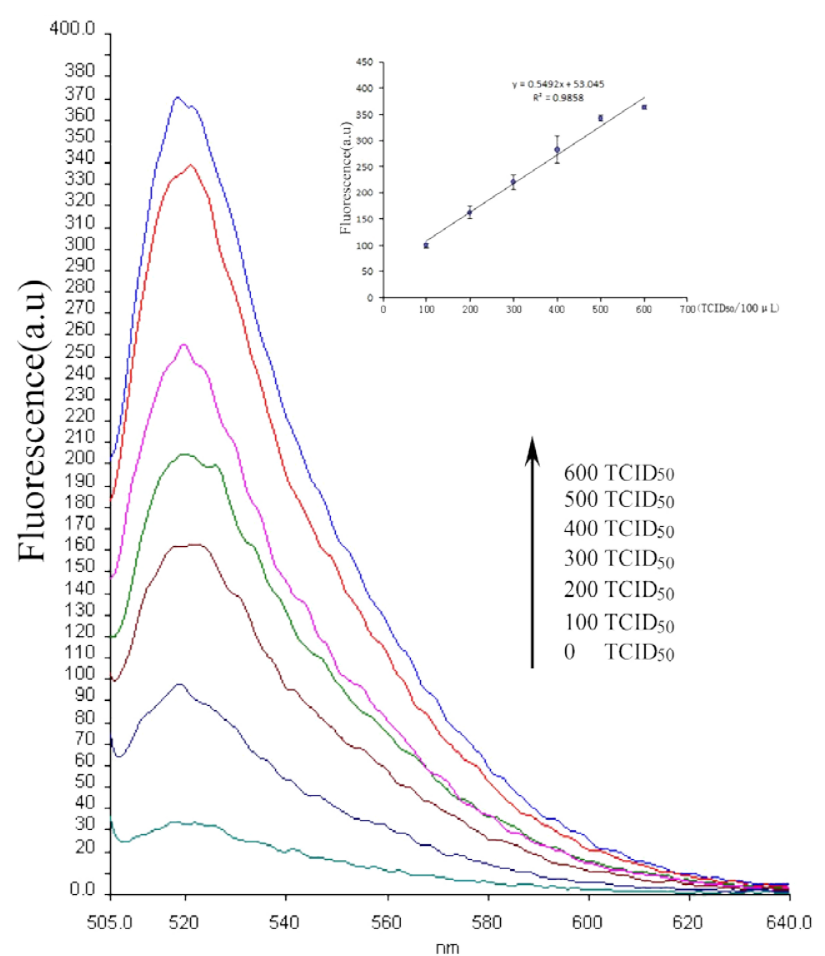

Figure 5a: The detection of the sample virus with different titers. Fluorescence intensity detection. The virus titers are varied from 0 to $6 \times 10^{2}$ TCID50 $(100 \mu \mathrm{L})$ from the bottom up. The inserted figure shows that the increases in fluorescence intensity and absorbance value are proportional to the concentration of target virus. Thecorrelation equation is $Y=0.5492 X+53.045$ while with a regression coefficient of 0.9858

As for selectivity, it was found that fluorescent intensity of the target virus ( $\mathrm{H} 1 \mathrm{~N} 1)$ is greater than that of non-target ones (Figure 5B). It was further confirmed that our method was highly selective and specific not only for HA protein but also for the whole influenza virus.

\section{Conclusion}

In summary, a ssDNA aptamer against HA protein of the subtype H1N1(A/Puerto Rico/8/1934) was successfully obtained by employing 
Citation: Feng X, Liu K, Ning Y, Chen L, Deng L (2015) A Label-free Aptasensor for Rapid Detection of H1N1 Virus based on Graphene Oxide and Polymerase-aided Signal Amplification. J Nanomed Nanotechnol 6: 288. doi:10.4172/2157-7439.1000288

Page 5 of 6

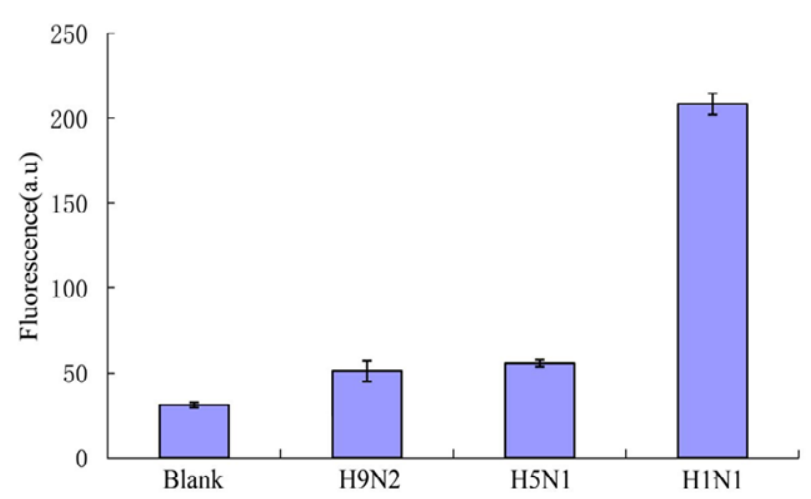

Figure 5b: The detection specificity of the proposed KF polymerase-based signal amplification for virus assay. The titer of H1N1 was $3 \times 10^{2}$ TCID50 (100 $\mu \mathrm{L})$ compared with other virus, H9N2 and H5N1. Each titer was measured three times and averaged.

asymmertric PCR-based SELEX. Based on this, the assay using KF polymerase-aided signal amplification and GO-based fluorescence quenching showed sensitivity and good selectivity with a detection limit of $2.5 \mu \mathrm{g} / \mathrm{mL}$ for HA protein and had been successfully applied in real samples with a low limit of $10^{2}$ TCID50. As a highly sensitive quenching platform GO has been widely applied in many biomolecule detections. The detection method constructed by Chen was based on the quenching action of GO, and its aptamer need to be labeled with carboxy fluorescein (FAM) [19].

Sheng also used GO for detection without enzyme [23]. Comparatively, two advantages are displayed in our work. Firstly, the labeled aptamer is not required. Secondly, a large amount of dsDNA were generated and the signals were significantly amplified when the strand displacement reaction would be triggered by KF polymerase. Based on the above characters, the aptasensor can effectively detect H1N1 with a lower limit of $1 \times 10^{2}$ TCID50 in $80 \mathrm{~min}$, which is shorter than $2.5 \mathrm{~h}$ [30]. Moreover, the assay is easy to operate and simpler than the commercial real-time NASBA assay [31]. More important, it is easily applied in developing countries and other remote areas. Our further study will be focused on that the selected aptamer might be coupled with DNA nanotechnology to achieve more versatile functions as the strategy and to be widely applied in biomedicine [32,33].

\section{Acknowledgement}

We would like to thank National Natural Science Foundation (81271660) and the Specialized Research Fund of the Ministry of Education for the Doctora Program of Higher Education (20114306110006), the Cooperative Innovation Center of Engineering and New Products for Developmental Biology of Hunan Province for financial support.

\section{References}

1. Skehel JJ, Wiley DC (2000) Receptor binding and membrane fusion in virus entry: the influenza hemagglutinin. Annu Rev Biochem 69: 531-569.

2. Eckert DM, Kim PS (2001) Mechanisms of viral membrane fusion and its inhibition. Annu Rev Biochem 70: 777-810.

3. Skehel JJ, Cross K, Steinhauer D, Wiley DC (2001) Influenza fusion peptides. Biochem Soc Trans 29: 623-626.

4. Samji T (2009) Influenza A: understanding the viral life cycle. Yale J Biol Med 82: 153-159.

5. Okazawa A, Maeda H, Fukusaki E, Katakura Y, Kobayashi A (2000) In vitro selection of hematoporphyrin binding DNA aptamers. Bioorg Med Chem Lett 10: $2653-2656$
6. Tang J, Xie J, Shao N, Yan Y (2006) The DNA aptamers that specifically recognize ricin toxin are selected by two in vitro selection methods. Electrophoresis 27: 1303-1311.

7. Wang L, Liu X, Zhang Q, Zhang C, Liu Y, et al. (2012) Selection of DNA aptamers that bind to four organophosphorus pesticides. Biotechnol Lett 34 869-874.

8. Deisingh AK, Thompson M (2004) Biosensors for the detection of bacteria. Can J Microbiol 50: 69-77.

9. Li H, Ding X, Peng Z, Deng L, Wang D, et al. (2011) Aptamer selection for the detection of Escherichia coli K88. Can J Microbiol 57: 453-459.

10. Perkins AC, Missailidis S (2007) Radiolabelled aptamers for tumour imaging and therapy. Q J Nucl Med Mol Imaging 51: 292-296.

11. Binning JM, Leung DW, Amarasinghe GK (2012) Aptamers in virology: recent advances and challenges. Front Microbiol 3: 29.

12. Xing H, Hwang K, Li J, Torabi SF, Lu Y (2014) DNA Aptamer Technology for Personalized Medicine. Curr Opin Chem Eng 4: 79-87.

13. Zhou J, Swiderski P, Li H, Zhang J, Neff CP, et al. (2009) Selection, characterization and application of new RNA HIV gp 120 aptamers for facile delivery of Dicer substrate siRNAs into HIV infected cells. Nucleic Acids Res 37: 3094-3109.

14. Feng H, Beck J, Nassal M, Hu KH (2011) A SELEX-screened aptamer of human hepatitis $B$ virus RNA encapsidation signal suppresses viral replication. PLoS One 6: e27862.

15. Woo HM, Kim KS, Lee JM, Shim HS, Cho SJ, et al. (2013) Single-stranded DNA aptamer that specifically binds to the influenza virus NS1 protein suppresses interferon antagonism. Antiviral Res 100: 337-345.

16. Gopinath SC, Kumar PK (2013) Aptamers that bind to the hemagglutinin of the recent pandemic influenza virus $\mathrm{H} 1 \mathrm{~N} 1$ and efficiently inhibit agglutination. Acta Biomater 9: 8932-8941.

17. Jeon SH, Kayhan B, Ben-Yedidia T, Arnon R (2004) A DNA aptamer prevents influenza infection by blocking the receptor binding region of the viral hemagglutinin. J Biol Chem 279: 48410-48419.

18. Park SY, Kim S, Yoon H, Kim KB, Kalme SS, et al. (2011) Selection of an antiviral RNA aptamer against hemagglutinin of the subtype $\mathrm{H} 5$ avian influenza virus. Nucleic Acid Ther 21: 395-402.

19. Chen C, Zhao J, Jiang J, Yu R (2012) A novel exonuclease III-aided amplification assay for lysozyme based on graphene oxide platform. Talanta 101: 357-361.

20. Cui L, Lin X, Lin N, Song Y, Zhu Z, et al. (2012) Graphene oxide-protected DNA probes for multiplex microRNA analysis in complex biological samples based on a cyclic enzymatic amplification method. Chem Commun (Camb) 48 194-196.

21. Hossain MT, Shibata T, Kabashima T, Kai M (2010) Aptamer-mediated chemiluminescence detection of prion protein on a membrane using trimethoxyphenylglyoxal. Anal Sci 26: 645-647.

22. He Y, Wang ZG, Tang HW, Pang DW (2011) Low background signal platform for the detection of ATP: when a molecular aptamer beacon meets graphene oxide. Biosens Bioelectron 29: 76-81.

23. Sheng L, Ren J, Miao Y, Wang J, Wang E (2011) PVP-coated graphene oxide for selective determination of ochratoxin $A$ via quenching fluorescence of free aptamer. Biosens Bioelectron 26: 3494-3499.

24. Li GZ, Tian F (2013) Guanine-decorated graphene nanostructures for sensitive monitoring of neuron-specific enolase based on an enzyme-free electrocatalytic reaction. Anal Sci 29: 1195-1201.

25. Liu X, Aizen R, Freeman R, Yehezkeli O, Willner I (2012) Multiplexed aptasensors and amplified DNA sensors using functionalized graphene oxide: application for logic gate operations. ACS Nano 6: 3553-3563.

26. Liu X, Wang F, Aizen R, Yehezkeli O, Willner I (2013) Graphene oxide/nucleicacid-stabilized silver nanoclusters: functional hybrid materials for optical aptamer sensing and multiplexed analysis of pathogenic DNAs. J Am Chem Soc 135: 11832-11839.

27. Levi R, Beeor-Tzahar T, Arnon R (1995) Microculture virus titration--a simple colourimetric assay for influenza virus titration. J Virol Methods 52: 55-64.

28. Pang S, Gao Y, Li Y, Liu S, Su X (2013) A novel sensing strategy for the 
Citation: Feng X, Liu K, Ning Y, Chen L, Deng L (2015) A Label-free Aptasensor for Rapid Detection of H1N1 Virus based on Graphene Oxide and Polymerase-aided Signal Amplification. J Nanomed Nanotechnol 6: 288. doi:10.4172/2157-7439.1000288

Page 6 of 6

detection of Staphylococcus aureus DNA by using a graphene oxide-based fluorescent probe. Analyst 138: 2749-2754.

29. Selvin PR1 (2000) The renaissance of fluorescence resonance energy transfer Nat Struct Biol 7: 730-734.

30. Zhao J, Tang S, Storhoff J, Marla S, Bao YP, et al. (2010) Multiplexed, rapid detection of H5N1 using a PCR-free nanoparticle-based genomic microarray assay. BMC Biotechnol 10: 74.
31. Moore C, Telles JN, Corden S, Gao RB, Vernet G, et al. (2010) Development and validation of a commercial real-time NASBA assay for the rapid confirmation of influenza A H5N1 virus in clinical samples. J Virol Methods 170: 173-176.

32. Li X, Zhang C, Hao C, Tian C, Wang G, et al. (2012) DNA polyhedra with T-linkage. ACS Nano 6: 5138-5142.

33. Bi S, Dong Y, Jia X, Chen M, Zhong H, et al. (2015) Self-assembled multifunctional DNA nanospheres for biosensing and drug delivery into specific target cells. Nanoscale 7: 7361-7367. 